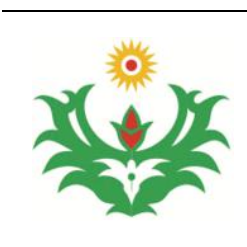

Linguistik Terapan 14 (2) (2017): 100-109

Jurnal Linguistik Terapan Pascasarjana

Available online

http://jurnal.unimed.ac.id/2017/index.php/JLT-Unimed

\title{
TRANSLATION PROCEDURE USED IN QUICK REFERENCE OF COMPAQ NOTEBOOK PC
}

\author{
Indah Sari Ayu Nasution \\ Rahmad Husein \\ Zainuddin \\ Linguistik Terapan Bahasa Inggris Universitas Negeri Medan
}

Diterima Agustus 2017; Disetujui oktober 2017; Dipublikasikan Desember 2017

\begin{abstract}
The aims of this study were to find out the types of translation procedures in the translation of Quick Reference of Compaq Notebook PC from English into Indonesian, and to describe the ways of proceduer translated in contextual situation from English into Indonesian. The research was conducted by using descriptive qualitative design. The data of this study were word,phrase,clouse and sentence that were translated from English into Indonesian on a book of "Quick Reference of Compaq Notebook PC as the source of data. Besides that, the data was analyzed by using translation procedure based on (Newmark,1988) which used to answer the questions number one and two to find the types and ways of translation procedure were used in Quick Reference of Compaq Notebook PC.The results of this study were found that there were eleven types of translation procedure used in translation of Quick Reference of Compaq Notebook PC namely transference, naturalization, culture equivalent, functional equivalent, synonymy, through translation, shift or transposition, modulation, recognised equivalent,componential analysis and reduction and expansion.The context of Translation procedure used in Quick Reference of Compaq Notebook PC were context situation based Halliday (1987) which used to answer the question number three.It consists of field,tenor and mode.
\end{abstract}

Keywords: Quick Reference, Compaq Notebook PC, Translation Strategies 
How to Cite: Nasution, Indah Sari Ayu (2017).

Translation Procedure Used in Quick Reference of ompaq Notebook PC. Jurnal Linguistik Terapan Pascasarjana Unimed, 14 (2): 100-109

ISSN 2407-7410

\section{INTRODUCTION}

Language plays an important role in the daily life of human being. People use language to communicate each other. Different languages have different ways of expressing, since it deals with the language functions. Therefore, to understand the ideas carried at in meaning, translation is needed to transfer the message between two different languages. Translation is a process of finding the textual equivalence of the Source Language (SL) in the Target Language (TL) to convey the meaning. The translation is expected to bridge the differences. Translation is not only in written but also in spoken. But, translation is not an easy thing to do by just translating word for word. Therefore, there are some words that cannot be understood from the SL to the TL.

Notebook is one of the gadget which many people use in working, specially for the students. Generally the electronic product such as notebook has language that is not easy to understand and translete. That is why every electronic product always attaches the manual book. It is useful to operate for the users. Beside the manual books always use English as source language and then translated into Indonesian language as target language. This things function to get easy to use it. Although sometimes the translation of the manual book is closer to English as the source language. This things also appears some questions how the procedure to translate source language to target language, specially the technology terms that is still considered diffucult and complex. Newmark (1988:5) states that translation is rendering the meaning of a text into another language in the way that the author intended the text. It means that to infer that translation is the process of transferring meaning from source language into target language. Otherwise Newmark (1988) has proposed some translation procedures which are used for sentences and the smaller unit of language, example words and phrases. Translation procedures are served by Newmark as constitute way to translate source text English into target text Indonesia. One of them are the procedure in translating manual book which the translation from English to Indonesian or Indonesian into English. The translator must be careful in transferring the meaning due to the fact that meaning is very important in translation activity. If the translator cannot get the right meaning from source language, the result of the translation will be mislead. For instance

\section{SL : Hardware component \\ $\mathrm{TL}$ : Komponen perangkat keras}


Based on the sample above, it is clear that the source language "component" when it was translated into Indonesian language as target language to be "Komponent". The procedure to translate that word used naturalization procedure. It means to adapt the SL word "Component" to the normal pronouncation become "Komponent", and then to the normal morphology of the TL in order to make it familiar to the TL audience. It succeeds transference.

Furthermore to translate technology terms contains in manual book is not only one procedure. But the translator can use another variant procedure. For instance.

\section{SL : Update \\ TL : Menggunakan versi terbaru}

Based the sample above it shows that the SL "Update" when it was translated into Indonesia as TL become "Menggunakan versi terbaru". It used expansion procedure in translating its meaning. Because expansion is used more words in the target text (TT) for re-expressing an idea or reinforcing the meaning of source text (ST) words because the lack of a concise correspondence in the target language.

Moreover another procedure to translate from manual text that contain technology terms can also be seen in some other variant procedure as follow:

\section{SL : A power surge, or system failure \\ TL : Naik turun tegangan listrik atau ganguan sistem}

Based the sample above the phrase A power surge when it is translated into Indonesia become Naik turun tegangan listrik. It is kind of expansion procedure in translating source language to the target language. Expansion is used for practising intuitively in some cases, ad.hoc in others and then for each there is at least one shift which we may like to bear in mind, particularly in poorly written text.

As describe above, translation procedures are used as tool of to transfer the meaning from a text. It aims to find the readable meaning in translating source language to target language. Besides knowing the kinds of translation procedure, the translator also should know and master the ways to translate texts which the translation product can be acceptable for the readers and users.

As a good translator, the translator has to know the equivalency of meaning in translating the SL to the TL. According to Baker (1992) equivalence is any meaning from the SL which expresses the same meaning in the TL, while a shift in Catford's term or transposition (Vinay and Darbelnet) is a translation procedure involving a change in the grammar from SL to target one.

When the SL and the TL are widely different in structure and cultural background, there cannot be an exact equivalent transferred from the SL into the TL. To overcome the differences in characteristics of these languages, the translator is required to understand the structure and culture of both languages. It can 
be said that translation is a complicated process encompassing both linguistic and non-linguistic problems.

In fact, the process of finding equivalents in the two languages is that the translator should first decode the ST, that is, to figure out the meaning, message and intention of the original speaker or writer and then ask himself or herself how the same decoded meaning, message and intention is encoded in the target text (TT).

So, the translator as the person who plays an important role in conveying the message of SL should not only master the language but also be competent in finding the closest natural equivalent of TL lexical items.

In translating, a good translator should understand not only the language but also the culture of both, the SL and the TL. In the process of translating the technology terms, a translator needs to know the procedure to render meaning in SL into TL properly.

Based on the description above, then it is considered to analyze the types of translation procedures used in the translation of Quick Reference of Compaq Notebook Pc into Indonesian, the process of translation procedures used in translating Quick Reference of Compaq Notebook Pc from English into Indonesian and the context of the translation procedures used in translating Quick Reference of Compaq Notebook Pc from English into Indonesian.

\section{RESEARCH METHODOLOGY}

The method of this study is descriptive qualitative. The data of the study were words, phrases, clauses and sentences from Quick Reference Compaq notebook PC (2012). And source of data in this study were Quick Reference Compaq Notebook PC (2012) that consisted of thirty one pages from Source language and while target language consisted of thiry one pages.

In data analysis, the researcher used the interactive model Miles, Huberman and Saldana (2014) state that this method consists of methodology by namely: data, condensation, data display and verification/ conlusion drawing.

Trustworthiness is the corresponding term used in qualitative research as a measure of the quality of research. Trustworthiness is the extent to which the data and data analysis are believable and trustworthy. Lincoln and Guba (1985) suggest that the trustworthiness of qualitative research can be established by using four strategies: credibility, transferability, dependability, and conformability. 


\section{FINDINGS AND DISCUSSIONS}

\section{Findings}

Based on the data anlysis, some research findings were specified below:

There were elevenn types of translation procedure used in translation of Quick Reference of Compaq Notebook Pc from English to Indonesian language, namely transference, naturalization, cultural equivalent, functional equivalent, synonymy, throu gh translation, shift or transposition, modulation, rcognised equivalent,componential analysis and reduction and expansion.

There were some ways of translation procedure used in Quick Reference of Compaq Notebook PC from English into Indonesian language such as transference, naturalization, cultural equivalent, functional equivalent, synonymy, through-translation, shift or transposition, modulation, rcognised equivalent,componential analysis and reduction and expansion.

While context of translation procedures of Quick Reference of Compaq Notebook PC used namely in context situation. This situation context consits of field, tenor and mode that occured in translation of technology terms.

\section{Discussion}

After analyzing the data, there were some points that considered as the important things to be discussed:

In this study was found that eleven types of translation procedures were used in Quick Reference of Compaq Notebook PC from English to Indonesian language, namely transfere nce, naturalization, cultural equivalent, functional equivalent, synonymy, through translation, shift or tran sposition, modulation, rcognised equivalent,componential analysis and reduction and expansion.

While Mashhady, Pourgalavi \& Fatollahi (2015) in their international journal Iran entaittled “Newmark's Procedures in Persian Translation of Golding's Lord of the Flies". It studied about Numerous frameworks and procedures have been proposed for translation. In this regard, the Newmark's proposed procedures have been widely discussed in translation studies. Yet, few studies have ever applied his procedures simultaneously for describing and assessing translations. This paper is an attempt to compare the translation procedures used in two Persian translations of Golding's Lord of the Flies by Rafiee and Mansoori based on Newmark's translation procedures. The main question is if the translator's procedures can be described and assessed by Newmark's framework or not. To do so, first, some chapters of the English novel were randomly selected, and then, they were compared with their corresponding 
parts in the Persian translations. Then, comparisons were classified and analyzed in terms of transliteration, shift, synonymy, modulation, addition, omission, as well as mistranslation to find out which procedures were used more by the two translators, and to show the extent of the mistranslated items in the two translations. The results showed that Newmark's procedures are nearly comprehensive and worked well for translating and assessing the translation of a literary work.

And then Maxinatila (2012) the title of this thesis is "The Translation Procedure of Prepositions from, for and with in J.K. Rowling "s Harry Potter and the Goblet of Fire". it is aimed at finding out the translation procedure of Prepositions from, for and with in the novel Harry Potter and the Goblet of Fire into Indonesian. Second, it is aimed at if whether the Prepositions from, for and with in the novel Harry Potter and the Goblet of Fire are always translated into Indonesian or not. Proportional random sampling was used to select the sample. The data of this study were analyzed by using three steps. First, describing the translation of Preposition from, for and with according to their uses in types of Adverbial Prepositional Phrase, Prepositional Object and Adjectival Prepositional Phrase. Second, analyzing the translated prepositions from, for and with in context according to the procedures of translation, those are Word for word translation, literal translation, faithful translation, semantic translation, free translation, communicative translation, transposition and modulation. Third, finding out and analyzing the untranslated prepositions from, for and with. The reasons of the sentences that include into each of the translation procedures are : the word are translated singly because the words in the source text has the same equivalent in the target text; the grammatical constructions are converted to the nearest target language equivalent; to reproduce the precise contextual meaning of the original within the constraint of the target language grammatical structure; the target language sounds more natural and beautiful; there are some specific changes in the target language and the sentences are conveying information to the readers.

The context of translation procedures of Quick Reference of Compaq Notebook PC used namely in context situation. This situation context consits of field, tenor and mode based on ( Halliday 1977, 1978) that occurred in translation of technology terms. While from previous research of Melby and Foster (2010) in their international journal entittled " Context in Translation: Definition,Access and Teamwork " was found that An individual word, such as 'key' (to a door? on a keyboard?) cannot be translated in isolation, unless the target language happens to maintain the same ambiguity as the source language. However, there is a lesser degree of consensus on the full extent of what comprises context in the world of translation and who is responsible for providing it. After a brief survey of prior discussion of context in 
translation, this article derives a five aspect, translation-specific definition of context from one general description.Section 2 of this paper then describes these five aspects of context, termed co-text, rel-text, chron-text, bi-text, and non-text. Three of these aspects are monolingual: portions of a text (co-text), versions of a text (chron-text), and related text (rel-text). The fourth aspect (bi-text) covers bi-lingual resources. And the fifth aspect (non-text) is beyond text. Section 3 demonstrates, through real-life examples, that each of the five aspects is indeed relevant to the work of a translator and that translators thus need access to all aspects of context. Section 4 asks a broader question: "How can everyone in the multilingual communication industry work together to improve translations through providing and using needed context?" This article is directed at a broad audience that reaches beyond those who conduct research in Translation Studies and includes translators, translation project managers, buyers of translation services, and those responsible for the authoring of texts that will be translated. Hopefully, an increased understanding of the importance of context will help everyone involved in multilingual communication to better cooperate in providing appropriate, efficient, and effective translations.

Analyzing a translation text is simple work especially to produce a good translation, eventhough translation that related with technology terms. Because a good translation is a text which is a translation (i.e.equivalent) in respect of those linguistic features which are most valued in the given transaltion (Stainer,2001:1)

The various application of procedures in overall translation, it just goes to one goal namely, the accuracity to find a good translation product. The accuracy of translation process needs to avoid a worst translation product namely distortion. Or eventhough, the lost of meaning from source language in translation text. For instance it occurs phraprasing by additon,deletion and hide meaning from source language into target language.

Beside, to produce a good translation namely by creating the dynamic equivalence meaning, it will creat the similar meaning (Nida.1982:73) and it is also stresses by Catford (1965:21) explains that The central problem of translation practice is that of finding TL translation Equivalents (ST and TT) then produce and create a right translation, acceptable and equivalent based on principles of translation ideology compeletely contains text message from source language (Hoed in Silalahi, 2010). 


\section{CONCLUSIONS}

From the overall anlysis of the translation procedure used in translation of Quick Reference of Compaq Notebook Pc, it could be concluded that:

1. There were eleven types of translation procedure used in translation of Quick Reference of Compaq Notebook Pc from English to Indonesian language, namely transference, naturalization, cultural equivalent, functional equivalent, synony my, through translation, shift or transposition, modulation, recognized equivalent, componential analysis and reduction and expansion.

2. There were some ways of translation procedure used in Quick Reference of Compaq Notebook PC from English into Indonesian language such as transference, naturalization, cultural equivalent, functional equivalent, synonymy, through-translation, shift or transposition, modulation, recognized equivalent, componential analysis and reduction and expansion.

3. While context of translation procedures of Quick Reference of Compaq Notebook PC used namely in context situation. This situation context consists of field, tenor and mode that occurred in translation of technology terms.

\section{REFERENCES}

Baker, 1992. In Other Words: A Course Book on Translation. London: Routledge.

Catford, J. C. 1965. A Linguistic Theory of Translation. London: Oxford University Press.

Derewianka, Beverly. 2004. Exploring How Texts Work. Australia: Primary English Teaching Association

Duff, A. 1989. Translation. London: Oxford University Press.

Fedora, L..2015. An Analysis of Procedures in Translating Cultural Words and Their Meaning Shift Found in the Indonesian Novel Laskar Pelangi. Vivid Journal Vol.4 No.1English Department, Andalas University.Accessed on June 7,2016

Hadithya, O. 2014. Translation Procedures Used in Translating Computer Terms from English into Bahasa Indonesia. Vivid Journal of English Department, Faculty of Humanities, Andalas University Vol.3 No.2. Accessed on February 28, 2016. 
Halliday, M.A.K. 1977. "Text as Semantic Choice in Social Contexts" in Teun A.van Dijk \& Jonoss Petofi (eds.), Grammars and descriptions: studies in text theory and text analysis. Berlin: Walter de Grugter: 176-225.

Halliday, M.A.K. 1978. Language as social semiotic: the social interpretation of language and meaning. London: Edward Arnold.

Halliday and Hasan (1985). Language, context, and text: aspects of language in social-semiotic perspective. Geelong, Victoria: Deakin University Press.

Halliday, M.A.K. dan Ruqaiya Hasan. 1992. Bahasa, Teks, dan Konteks. Yogyakarta: Gadjah Mada University Press

Haque, M. Z. 2012. Procedure of Translating Literary Prose: Problems and Solutions. International Journal of English Linguistics; Vol. 2, No. 6; 2012 ISSN 1923-869X E-ISSN 19238703 Published by Canadian Center of Science and Education. Accessed on May 6, 2016.

Jakobson, R. 1959. 'On Linguistic Aspects of Translation', in R. A. Brower (ed.) On Translation, Cambridge, MA: Harvard University Press.

Larson, M. L. 1984. Meaning-Based Translation: A Guide to Cross-Language Equivalence. Lanham, MD: University Press of America.

Larson, M.L 1998. Meaning Based Translation. A Guide to Cross-Language Equivalence. Second Edition. New York: University Press of America.

Lincoln, Y.S. \& Guba, E.G. 1985. Naturalistic Inquiry. Newbury Park, CA: Sage.

Martin, James R. (1992). English Text: System and Structure. John Benjamins: Amsterdam.

Martin, J.R., Matthiessen, C. M. I. M., \& Painter, C. 1997. Working with Functional Grammar. London: Arnold.

Mashhady, \& Fatollahi 2015 in their International Journal Iran entaittled "Newark's Procedures in Persian Translation of Golding's Lord of the Flies".Accessed on February 2, 2016.

Maxsinatalia.2012. The Translation Procedure of Prepositions from, for and with in J.K. Rowling's Harry Potter and the Goblet of Fire. Thesis English Department, UDINUS Semarang. accessed on April 1, 2016.

Miles, M. B \& Huberman, A. M. 2014. Qualitative Data Analysis: A Methods Sourcebook, Calofornia: The Third Edition. Sage Publication.Inc. 
Nababan, 2003. Teori Menerjemah BS. Yogyakarta: Percetakan Pelajar.

Nababan, M.R. 2004. Translation Processes, Practices and Products of Professional Indonesian Translators. Unpublished Thesis. School of Linguistics and Applied Language Studies, Victoria Univ of Wellington, New Zealand.

Naraswari, W.S.\& Nugroho, R.A.Translation Procedures of Culture Bound Words Used in Visitor Guide of Jawa Tengah. Journal Article Udinus Semarang. Accessed on April 24, 2016.

Newmark, P. 1988. A Textbook of Translation. New York: Prentice Hall.

Nida, E.A. and Charles R. Taber. 1969. The Theory and Practice of Translation. Leiden: E.J.Brill.

Nida, E.A \& Taber. 1974. The Theory and Practice of Translating. Leiden: Brill.

Nida, T. 1982. The Theory and Practice of Translation. Leiden: E. J. Brill.

Www.http://language.la.psu.edu/tifle2002/halliday.html

Www.thttp://artic.acbesancon.fr/anglais/docsword/write/anarrativ/text/D..doc) 